\title{
Canadian Interstate Federalism and Economic Globalization
}

\section{Derek Carnegie}

\section{University of Toronto}

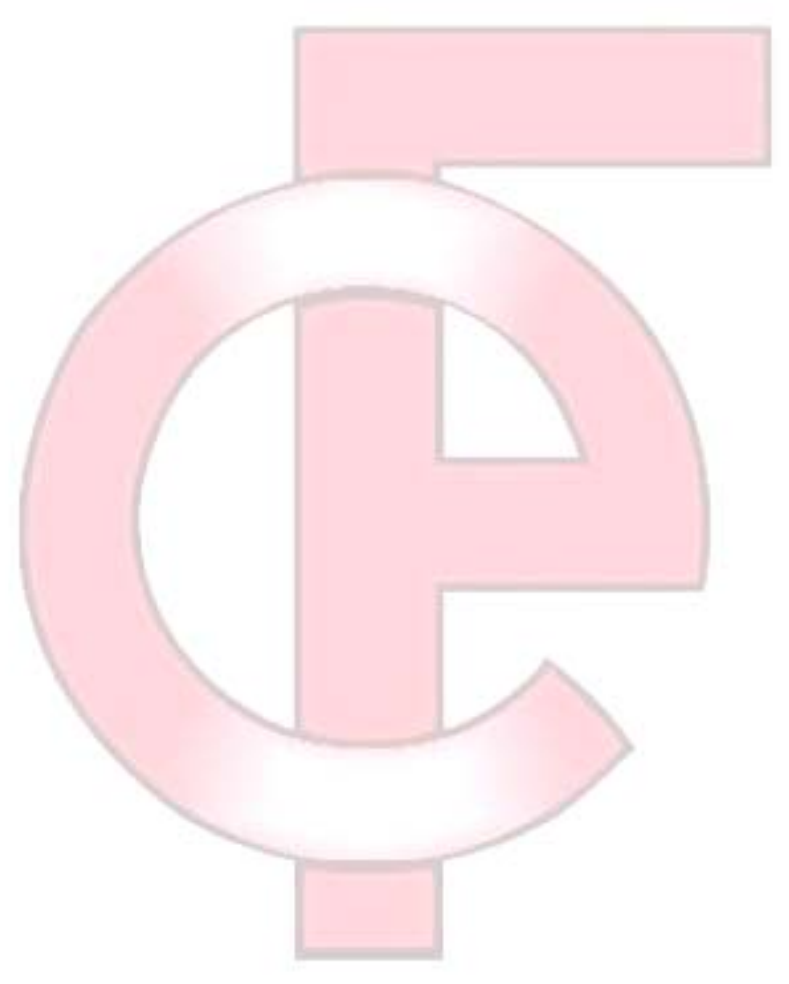

Derek Carnegie is in the third year of his undergraduate studies at the University of Toronto in the joint political science and economics program. He has recently developed an interest in Canadian studies, and has spent much of the past year working on a faculty research project regarding North American trade and investment flows in key economic sectors. Upon graduating, Derek plans to pursue graduate studies in comparative politics. 


\section{Introduction}

Despite the development of a general agreement that the processes of globalization weaken national borders, little attention has been paid until recently to the impact of these processes on the internal borders of federal systems. These discussions take on particular urgency in Canada, a country which is both trade-dependent and defined in large part by its federal structure (Simeon, 2003 p.132). This paper examines the responses of the provinces and systems of interstate federalism to economic globalization, particularly the negotiation and implementation of the GATT/ WTO agreements since the Tokyo Round and FTA/ NAFTA agreements. Though these responses have been ad hoc and incomplete, they have developed a flexible approach which has balanced federal and provincial interests in the midst of largely centralizing trends.

In addition to the already decentralized nature of the Canadian federation, the present intergovernmental approach to foreign trade has been the result of a unique and ambiguous interpretation of an outdated constitutional power. An overview of this matter is followed by an analysis of the Canadian response to the centralizing forces of global and continental economic integration.

\section{Constitutional History}

Section 132 of the 1867 BNA Act gave the Canadian parliament the right to enact the terms of treaties agreed to by the British Empire (Tuck, 1941 p.38). By the early 1900s, the British role had been reduced to the signing of Canadian-negotiated treaties (Leeson, 1977 p. 511). Despite the J CPC declaration in the 1932 Radio Reference ${ }^{1}$ that Section 132 no longer operated after the end of the British Empire, it appeared that Ottawa had assumed authority over foreign affairs by means of the POGG and trade and commerce powers (Lesson, 1997 p.511; Mahler, 1987 p.111).

This changed after the federal government attempted to pass legislation in 1935 regulating hours of work and minimum wages in accordance with International Labour Organization agreements. While the Supreme Court of Canada upheld the right of the federal government to enact legislation in accordance with an international treaty, the J CPC found the federal government to be acting ultra vires, effectively reversing the decision made in the

\footnotetext{
${ }^{1}$ In the Radio Reference, the JCPC upheld the ability of the federal government to regulate radio frequencies in accordance with International Radiotelegraph Convention, even though the control over such local matters was a provincial responsibility (Kukucha, 2005 p.134). This ruling therefore suggested that Ottawa had the ability to sign international agreements which dealt with provincial matters.
} 
Radio Reference (Leeson, 1997 p.512; Mahler, 1987 p.112). While the Supreme Court generally expanded the scope of the POGG and trade and commerce powers after 1949, the Labour Conventions case seriously reduced the ability of the federal government to unilaterally pass treaty legislation in areas of provincial jurisdiction (Kukucha, 2005 pp.136-144).

As observed by Hülsemeyer, the present Canadian constitution is unusual in that in some areas it separates the abilities to make and implement treaties between two orders of government (2004 p.92). The existence of the provincial veto power which was ambiguously established in the Labour Conventions case has encouraged negotiation through the existing structures of executive and administrative federalism (Hülsemeyer, 2004 p.93; Luz \& Miller, 2002 p.996). This has resulted in a less systematic approach to international trade by the federal and provincial governments. Attempts to repair this situation were made in the Meech Lake and Charlottetown Accords, but would have been of questionable value had they passed, due to their vaguely-defined roles for provincial governments (Rocher \& Nimijean, 1995 pp.224-226). Since the failure of the Charlottetown Accord, no significant proposals have been put forward to manage federal-provincial responses to international trade via the constitution. Appeals and references to the Supreme Court have also been avoided out of fear of clarifying the constitution in unfavourable terms (Kukucha, 2005 p.130). Few other permanent systems and institutions of negotiation have been pursued, as is illustrated below.

\section{Economic Globalization and Centralization}

The institutional stalemate has led to intergovernmental negotiation on a case-bycase basis. This has resulted in a uniquely balanced approach for the Canadian federation. As the terms of the agreements behind economic globalization reach further into the affairs of participant states, federal systems have generally seen the power of the central government increase relative to that of regional governments. Canada is noteworthy because intergovernmental consultation has moderated this trend. Although increased levels of trade have led to some centralization of power, the provinces have not lost as much authority to the central government as has been the case in other wealthy federations. Australia and the United States, which were both founded as centralized federal systems, have centralized further with the increased scope of recent trade agreements (see Galligan, 2003 and Kincaid, 2003). A constitutional transformation of Germany's horizontallydivided federalism has strengthened the 
collective voice of the Länder, though this has not significantly slowed the processes of centralization which have accompanied European integration (Hülsemeyer, 2004 pp.55-70).

There are three main aspects of economic globalization which act as centralizing forces. The first and most important of these is the gatekeeper position which the central government holds with respect to foreign affairs, a role which obviously takes on increased relevance with the proliferation of international trade discussions. Secondly, there is increased motivation for the federal government to police the actions of regional governments, since many trade agreements hold the federal government responsible for the actions of its subnational governments. This is likely done through the use of threats or incentives with the tools of fiscal federalism (Robinson, 1995 p.242). Finally, as observed by Rocher \& Nimijean, the nation-state and its institutions still represent the country's economic space, which gains importance in a context of free trade (1995 p.218). The remainder of this paper will examine in detail the Canadian responses to these forces and review potential issues of concern.

\section{The Provincial Voice in Trade Agreements}

The question of whether Ottawa acts as a restrictive "gatekeeper" concerns the provincial role in the negotiation of international trade agreements, and is therefore of critical importance. Though the consultative relationship which has arisen in the constitutional gap is often seen as conflictual and based on federal interests (see Robinson, 1995), issues of disagreement are exceptions to an otherwise cooperative process (Kukucha, 2005 p.144). Ontario's oppositions to the FTA under Peterson and the NAFTA under Rae were soon reversed by the Progressive Conservative government which embraced the market and tried to increase the province's competitiveness (Courchene, 1999

p.19). Although not a trade agreement, Alberta's vocal opposition to the Kyoto Accord was quieted prior to federal ratification through conferences similar to those used to negotiate trade positions (Kukucha, 2005 pp.146-148).

Provincial involvement provides valuable information on affected industries and regional interests, which may be costly to obtain otherwise (Brown, 1991 p.94). With growing exposure to the international market, a number of the provinces have formed significant trade links of their own. This has 
also strengthened their positions in intergovernmental negotiations, as they have gained a degree of autonomy from the federal government (Brown, 1991 p.83; Courchene, 1991 p.60). As illustrated in the following history, the role of the provinces in these international negotiations has expanded as the elements of trade agreements have further encroached upon their jurisdictions.

The structuring and implementation of international trade agreements with provincial involvement was infrequent prior to the commencement of the Tokyo Round of GATT negotiations in 1973. Earlier discussions had concerned only limited goals of tariff reduction, and were thus completely within federal jurisdiction (Brown, 1991 pp.90-91). The Tokyo Round introduced measures to reduce "nontariff barriers" to trade, which involved issues within provincial jurisdictions (Robinson, 1995 p.237). The only formal channel of provincial involvement, the Canadian Trade and Tariffs Committee, soon proved to be an insufficient medium of communication. In its place, a temporary committee of federal and provincial deputy ministers was created in 1975 (Hale \& Kukucha, 2004 p.8). This was also replaced in 1977 with the appointment of the Canadian Coordinator for Trade Negotiations. The CCTN was responsible for collecting input from provincial governments and concerned industries, and reported directly to the federal cabinet (Brown, 1991 p.91). While the final agreements of the Tokyo Round did not affect the provinces to the extent that had been anticipated, their involvement marked a new trend in Canadian foreign affairs (Anderson, 2001 p.50; Brown, 1991 pp.92).

The movement towards more comprehensive trade agreements continued with the Canada-U.S. Free Trade Agreement (FTA). The 1985 report of the Macdonald Commission, which had encouraged negotiation of a free trade deal with the United States, specifically suggested reaching an agreement between the federal and provincial governments prior to the bilateral negotiations. To accomplish this, the CCTN was expanded to form the Committee for the Free Trade Agreement (CFTA), which had an official representative from each province (Hale \& Kukucha, 2004 p.8). The CFTA was used with some success by provinces to ensure protection of industries and interests particularly relevant to their regions (Hülsemeyer, 2004 p.93). While the federal government did not include in the bilateral negotiations provincial issues which contradicted its own position, many of the clauses which fell under provincial jurisdiction were grandfathered to exempt noncompliance of existing laws (Hülsemeyer, 2004 p.94; Robinson, 1995 p.238) Such revision 
prevented provincial objections by restricting future instead of present governments (Robinson, 1995 p.238). When this is considered, the strong "federal state" clause included in the agreement seems less centralizing (Brown, 1991 p.97; Robinson, 1995 p.238).

In addition to introducing expanded regulations and a more formal structure in the form of the WTO, the Uruguay Round of GATT negotiations sought further changes to government subsidization programs (Hale \& Kukucha, 2004 p.4). From the launch of these negotiations in 1986, the CCTN was responsible for managing federal-provincial consultation. By 1990, subcommittees of the Committee on Multilateral Trade Negotiations were established to discuss specific items, while the federal Minister of International Trade met regularly with provincial ministers (Brown, 1991 p.100). The final agreement included unclear clauses on the grounds by which subsidy programs would bejudged, but is generally understood to have restricted the options of subnational governments more so than their central counterparts (Robinson, 1995 p. 243). In response, this period saw the establishment of ongoing initiatives to coordinate trade and economic policy between industry, citizens, Ottawa, and the provinces in forums such as CTRADE, the ITAC, and the
SAGIT, but these were generally weak and unsuccessful (Hale\& Kukucha, 2004 p.9; Skogstad, 1992 p.338; Smythe, 2001 p.151). CTRADE, for example, has been seen by many provinces as a tool for the expression of federal positions rather than a true forum for discussion (Kukucha, 2004 p.122). Although their ultimate influence has been less noticeable on the world stage, the larger provinces have regularly sent unofficial representatives to GATT/WTO negotiations to work alongside the federal delegation (Brown, 1991p.91).

Due to the more intrusive nature of the NAFTA agreement, Ottawa established the Committee for North American Free Trade Negotiations (CNAFTN) to operate alongside the still-functioning CFTA in a similar capacity for the duration of the talks (Hale \& Kukucha, 2004 p.9). The CNAFTN proved to be more collegial than the CFTA had been, and allowed for more in-depth consultation with the provinces (Hülsemeyer, 2004 p.100). Aside from the commercial NAFTA agreement, two side agreements were reached on labour (the NAALC) and the environment (the NAAEC) in the tripartite talks. The federal government constructed separate intergovernmental agreements for the provinces to opt-in to the NAALC and NAAEC, as a number of provinces have so far done. This domestic measure was 
the most important victory for the provinces. Established over the objections of the United States, these internal agreements gave the provinces the final authority over the aspects of the agreement which lay within their jurisdictions (Hülsemeyer, 2004 pp.98, 101, 102). Recent multilateral trade negotiations such as the Doha Round and FTAA talks have continued to feature provincial input, though the progress of these talks have been slower than previous initiatives (Hale \& Kukucha, 2004 p.6).

Although the terms by which the provinces participate in trade negotiations are at the discretion of the federal government, their involvement is clearly beyond that of token recognition. The provinces carry substantial influence, which they have used to indirectly shape federal positions and the resulting agreements.

\section{The Policing Role of the Federal Government}

The first point to make on this issue is that Canada has typically taken weak interpretations of the federal state clauses included in most international treaties (Kukucha, 2005 p.133). This reduces the motivation of the federal government to pressure the provinces for changes legislation, and has significantly reduced Ottawa's "policing" role (Simeon, 2003 p.156).

The two methods by which Robinson imagines that the federal government may pressure provinces are by directly legislating in the place of the provinces or, more likely, through the use of the spending power (1995 p.242). Any threats of federal legislation are unlikely to be taken seriously, given the previously-mentioned risks of an unfavourable Supreme Court ruling. The increasing provincial share of revenues has decreased the relevance of the spending power, while SUFA made it less volatile (Simeon, 2003 p.146). Although the power of disallowance remains a theoretical option for the federal government, it is difficult to imagine a return in its use (Rocher \& Nimijean, 1995 p.221).

In order to manage the issue-specific conflicts which have arisen after the signing of trade agreements, the provinces and federal government agreed that a non-judicial method of dispute settlement was required to coordinate domestic policy with international commitments (Brown, 1991 pp.100-107). The result was the 1994 Agreement on Internal Trade (AIT) (Hale \& Kukucha, 2004 p.7). The AIT was modeled on a similar mechanism of the FTA, and was quite successful in balancing intergovernmental concerns. Criticisms against the AIT include its exclusion of 
nongovernmental actors and the weaknesses of many of its provisions (Simeon, 2003 p.154).

Nevertheless, it stands out both as a permanent institution of discussion and decision-making among otherwise ad hoc committees and agreements, and as a representation of the increasingly cooperative arrangements between the two orders of government.

\section{The National Economic Space}

The argument that the nation-state continues to define the economic environment of a country is similar to the idea of the central government as a gatekeeper to the outside world, but instead takes an introverted point of view. If true, the increased relevance of economic interaction brought by globalization would inevitably lead to the weakening of subnational governments due to their lack of control over primary macroeconomic tools.

This has been borne out to an extent. National borders remain the most relevant to FDI, and the federal government is responsible for setting the general terms by which the national economy will operate (Luz \& Miller, 2002 p.975; Mahler, 1987 p.109). Control over monetary policy has obviously remained with the federal government, as has the trade and commerce power, which the Supreme Court has expanded upon since 1949 (Kukucha, 2005 p.129).
The above traits of the Canadian system are unlikely to change in the near future; however, the provinces have gained some influence over their respective economies in recent years. Deficit-driven decentralization and greater provincial power over tax rates have given the provinces more options in attracting investment (Simeon, 2003 p.147). The recent return of budget surpluses will further expand the list of possible options. Also, market forces are not as deterministic as is often assumed; a recent study found that corporate tax levels in the OECD have been diverging, and that there is a positive correlation between openness to trade and the size of the public sector (see Garrett, 1998). As the analysis of economic policies requires history to pull from, future commentators will be better positioned to dissect the subject. For now, it is important to note that the there is potential for significant provincial autonomy.

\section{Criticisms and Conclusion}

The provinces will not soon rival Ottawa for the ultimate authority over their economies, but the decentralization of some powers has allowed for a moderately regional response in Canada. Provinces make real contributions to international negotiations, cooperate with the federal government to work within the limits of the resulting agreements, and are increasingly 
taking control of their economies. Without straying too far into a normative evaluation of regional versus national approaches to globalization, there have been a number of problems with the present system of negotiation. Provincial governments may not accurately represent their regions, especially given the exclusion of metropolitan centres for interstate relations (Robinson, 1995 p.248;

Courchene, 1992 p.124). Others would argue that centralization is a more appropriate response to globalization, as it allows for equalization, a diversification of risk, and respect for non-territorial interests (Breton, 1995 p.150). However, the central theme of this paper has been the temporary and ad hoc character of the committees developed to reconcile federalism with an open trading policy. While this has arguably been what has allowed for the flexibility of the present arrangement, it has also made it difficult for the two orders of government to discuss longterm goals and set binding agreements prior to international negotiations. The full impacts of this will be more visible in the long run, though it has also contributed to the current exclusion of cities and groups not represented by provinces, as they lack regular access to the bodies of negotiation. The continued expansion of the trade and commerce power may encourage the provinces to call for the renewal of existing organizations such as CTRADE. In either direction, future reform must be judged carefully by governments who respect the motives for both national and regionalized approaches to economic globalization. 


\section{Works Cited:}

Anderson, George. "Canadian Federalism and Foreign Policy." Canada - United States Law J ournal 27.1(2001): 45-53.

Breton, Raymond. "Identification in Transnational Political Communities.” Rethinking Federalism: Citizens, Markets, and Governments in a Changing World. Ed. Karen Knop, Silvia Ostry, Richard Simeon, and Katherine Swinton. Vanouver: UBC Press, 1995. 40-58.

Brown, Douglas M. "The Evolving Role of the Provinces in Canadian Trade Policy." Canadian Federalism: Meeting Global Economic Challenges?. Ed. Douglas M. Brown and Murray G. Smith. Kingston: IRPP, 1991. 81-128.

Courchene, Thomas J . "Responding to the NAFTA Challenge: Ontario as a North American Region State and Toronto as a Global City-Region." Institute for Research on Public Policy October 1999. 28 July $2006<\mathrm{http}: / /$ www.irpp.org>.

Courchene, Thomas J . Rearrangements. Lanham, MD: Mosaic, 1992.

Courchene, Thomas J . The Community of the Canadians. Kingston: Queens, 1991.

Galligan, Brian. "The Centralizing and Decentralizing Effects of Globalization in Australian Federalism: Toward a new Balance." The Impact of Global and Regional Integration on Federal Systems. Ed. Harvey Lazar, Hamish Telford, and Ronald J. Watts. Kingston: Queens, 2003. 87124.

Garrett, Geoffrey. "Global Markets and National Politics: Collision Course or Virtuous Circle?.” International Organization. 52.3 (1998): 787-824.

Hale, Geoffrey \& Christopher Kukucha. “Investment, Trade and Growth: Multi-Level Regulatory Regime in Canada." Carleton University School of Public Policy and Administration October 2004. 4 August $2006<$ <ttp:/ / www.carleton.ca/sppa>.

Hülsemeyer, Axel. Globalization and Institutional Adjustment: Federalism as an Obstacle?. Cornwall: Ashgate, 2004.

Kincaid, J ohn. "Globalization and Federalism in the United States: Continuity in Adaptation." The Impact of Global and Regional Integration on Federal Systems. Ed. Harvey Lazar, Hamish Telford, and Ronald J. Watts. Kingston: Queens, 2003. 37-86.

Kukucha, Christopher. "The Role of the Provinces in Canadian Foreign Trade Policy: Multi-Level Governance and Sub-National Interests in the Twenty-First Century." Policy and Society 24.3 (2004): 113-134.

Kukucha, Christopher. "From Kyoto to the WTO: Evaluating the Constitutional Legitimacy of the Provinces in Canadian Foreign Trade and Environmental Policy." Canadian J ournal of Political Science. 38.1(2005): 129-152.

Leeson, Howard A. "Foreign Relations and Quebec." Canadian Federalism: Myth or Reality. Ed. J . Peter Meekison. Toronto: Methuen, 1977. 510-523. 
Luz, Mark A. \&Marc Miller. "Globalization and Canadian Federalism: Implications of the NAFTA's Investment Rules.” McGill Law J ournal. 47 (2002): 951-997.

Mahler, Gregory S. New Dimensions of Canadian Federalism: Canada in Comparative Perspective. Cranbury, NJ : Associated Universities, 1987.

Robinson, Ian. "Trade Policy, Globalization, and Canadian Federalism." New Trends in Canadian Federalism. Ed. François Rocher and Miriam Smith. Peterborough: Broadview, 1995. 234-269.

Rocher, François \& Richard Nimijean. "Global Economic Restructuring and the Evolution of Canadian Federalism and Constitutionalism." Trends in Canadian Federalism. Ed. François Rocher and Miriam Smith. Peterborough: Broadview, 1995. 211-233.

Simeon, Richard. "Important? Yes. Transformative? No. North American Integration and Canadian Federalism." The Impact of Global and Regional Integration on Federal Systems. Ed. Harvey Lazar, Hamish Telford, and Ronald J. Watts. Kingston: Queens, 2003. 125-172.

Skogstad, Grace. "The State, Organized Interests and Canadian Agricultural Trade Policy: The Impact of Institutions." Canadian J ournal of Political Science. 25:2 (1992): 319-347. J STOR. University of Toronto Lib., Toronto, On. 15J uly 2006 <http:// www.jstor.com/ >.

Smythe, Elizabeth. "Repoliticizing Globalization in Canada: From the MAI to Seattle." J ournal of Canadian Studies. 36.1(2001): 141-165.

Tuck, Raphael. "Canada and the J udicial Committee of the Privy Council." University of Toronto Law J ournal. 4.1(1941): 33-75. J STOR. University of Toronto Lib., Toronto, On. 15J uly 2006 <http://www.jstor.com/ >. 